\title{
"Thrown away like a banana leaf": precarity of labour and precarity of place for Tamil migrant construction workers in Singapore
}

Article

Accepted Version

Hamid, W. and Tutt, D. (2019) "Thrown away like a banana leaf": precarity of labour and precarity of place for Tamil migrant construction workers in Singapore. Construction Management and Economics, 37 (9). pp. 513-536. ISSN 01446193 doi: https://doi.org/10.1080/01446193.2019.1595075 Available at https://centaur.reading.ac.uk/82709/

It is advisable to refer to the publisher's version if you intend to cite from the work. See Guidance on citing.

To link to this article DOI: http://dx.doi.org/10.1080/01446193.2019.1595075

Publisher: Taylor \& Francis

All outputs in CentAUR are protected by Intellectual Property Rights law, including copyright law. Copyright and IPR is retained by the creators or other copyright holders. Terms and conditions for use of this material are defined in the End User Agreement. 


\section{CentAUR}

Central Archive at the University of Reading

Reading's research outputs online 


\section{"Thrown away like a banana leaf": Precarity of labour and precarity of place for Tamil migrant construction workers in Singapore}

ID: RCME-SI-17-0380

\section{Abstract:}

Despite labouring for three decades in Singapore, and being connected to the existing Tamil diasporic community there, Tamil migrant construction workers have been left out of state rhetoric and face economic marginalisation and social exclusion. In this article we draw on rich ethnographic data on their everyday experiences of working construction and living in Singapore, and we espouse the distinctive qualities and mission of ethnographically-informed methodologies to enact change in this space. The methods include in-depth interviews with 11 Tamil labourers, and the subsequent use of worker photo diaries, known as autophotography, with a total 108 photographs taken. All the participants either worked construction, were on medical leave, or were seeking compensation after workplace injury. The analysis of the interview data develops themes around precarity and discrimination on construction sites (precarity of work), and the exclusory social practices experienced by workers in their offsite world (precarity of place). Following the goals of decolonised research, our innovative methods have enabled Tamil construction workers to present their lives through their own lens. By involving migrant construction workers, we identify new sites of inquiry and knowledge in examining the inequalities and injustices they face.

Keywords:

Migrant workers; Singapore; Tamil construction workers; visual research methods; autophotography; ethnography. 


\section{Introduction:}

This article investigates the social marginalisation and precarious lives of low-waged Tamil construction workers in Singapore, offering a "face" and "voice" to their everyday experience through applied and innovative ethnographic methods. Tamil labour migration to Singapore is not a new phenomenon; while the global framing has changed from colonisation to globalisation, the flow of Tamil workers has continued to provide labour for the essential “3D” jobs (dirty, difficult and dangerous). These workers have been left out of state rhetoric and marginalised in society, often due to the state's claim of their "transient" status when they effectively constitute a semi-permanent structural element of the Singapore labour market (Hamid, 2014).

In addressing the lack of contemporary empirical research on Tamil migrants, this ethnographic research provides an account of their everyday experiences as opposed to their perception of being "faceless" and "voiceless" labourers (Schiller and Çağlar, 2011: 61). This article seeks to examine the precarity of labour and the precarity of place (Banki, 2013) in the everyday experience of Tamil construction workers in Singapore. Whilst this research cannot provide the basis for wide generalisation, we will illustrate how an ethnographic approach, utilising visual and participatory research methods (Rose, 2012), facilitates a better understanding of the socio-economic marginalisation of low-waged Tamil labourers in Singapore. In doing so, it also sheds a light on the role of NGO and applied research in this Special Issue of refiguring global construction challenges through ethnography. Indeed, we show how theoretically informed ethnography (with an interventionist aspect linked to social reform) can be highly creative and insightful for exploring and identifying innovative sites of inquiry and knowledge. We demonstrate how it can provide a space for the workers to 
represent themselves and counter misrepresentations, which, we argue, stem from an inequality heavily rooted in colonial legacy and neoliberal economic forces.

Despite the arguments of Pink, Tutt and Dainty (2012), that applied ethnographic interventions in the construction industry are very achievable, there has been little contemporary ethnographic research undertaken that engages directly with manual workers and/or the topic of working conditions in pages of the leading Construction Management research journals. This is especially the case in developing world contexts. We should acknowledge their call for ethnographic research "to respond to the emergent realities of practice and to localized contexts and specificities" (p.659). Yet, it will be clearly argued that, in the context of Singapore construction, reforms to migrant labour laws come not from applied research at construction sites and worker dormitories, but from engaging with construction workers once they leave site through injury, abandonment or absconding.

The article will first describe the Riot in Little India, Singapore, during the research period, as a starting point to address the specific migratory trajectory of this under-researched community of Tamil migrant construction workers and the social realities they face as they labour transnationally. We build out of this incident for two reasons. One, to highlight the context to our discussion of construction workers in Singapore and the links between the on/offsite worlds (Tutt et al, 2013b), and secondly to frame the spaces within which applied, participatory and NGO research with construction workers functions. Indeed, the paper will espouse the distinctive qualities and mission of ethnographically informed methodologies to enact change in this space, particularly through participatory methods and the use of worker photo diaries.

\section{Reacting to the Riot in Little India:}


In December 2013, a fatal traffic accident in Singapore's Little India involving a Tamil migrant construction worker grew into a 'riot'. It brought into prominence the presence of a large number of Tamil migrant workers (who are housed away at the peripheries of Singapore), their gathering in Little India on weekends, and the increased need of the Singapore authorities to manage and control such assemblies (Hamid, 2014). Xenophobic comments targeting Tamil workers filled online forums in Singapore (Lam, 2013). Local residents of Little India began writing to the newspapers calling for stricter control and further exclusion of migrant workers from Little India.

This event followed not long after researcher had undertaken fieldwork in the Tamil community. She felt a responsibility to address the issues and the lived realities, which she had encountered, and yet were strangely absent from the debate, and a guilt at the (limited) reach of her academic work. A day had gone past; researcher began looking through her research material and began writing a blog post (extract below) and sharing photographs taken by the workers. It was an attempt to show workers' everyday lives and circumstances, to communicate some of the hopes, dreams and commonalities of Tamil migrants and fellow Singaporeans.

Watching what happened on Sunday in Singapore's Little India made my heart sink. At one end of the line of fire were fellow Singaporeans while at the other end were Tamil migrant workers - a group I had been researching with for about 3 months, going to Little India every other day, undertaking fieldwork there while spending a whole year studying about them. Guilt overtook me yesterday. Despite having spent hours speaking with these low-waged Indian migrant workers and understanding them better, how have I contributed to people understanding them better? 
[My research had been] dedicated to all the Indian transient migrant workers and the people in Singapore who have been striving for their equal treatment. Though I thought I had given them a voice through my research, I may have failed. I fully acknowledge the gravity of the riot and do not condone the actions; [but] we need to address the elephant in the room... of how we have overlooked the existence of transient, low-waged migrant workers. As a Singaporean I myself have been guilty in the past of just passing by the migrant worker and ignoring their existence. We see them labouring on tall scaffoldings all over the island, we ride on the MRT-tracks they laid risking their lives, we live in the flats they built, we show [off to] the world over the amazing skyscrapers that they built for us, making us the leading global city in Asia ...BUT what do we know about them-except that they gather in Little India and get drunk on Sundays?

Researcher then quickly developed the blog post for publication on prominent migrant worker rights NGO website, Transient Workers Count Too (TWC2) (Hamid, 2013), through contacts and relationships forged through the fieldwork, to feed directly into the media debate. The theoretically driven ethnography, and social interventionist research agenda to enact change, was rapidly re-channelled and started to develop in new impactful ways. The subsequent exposure helped her to develop and design a new project of innovative participatory research, with migrant construction workers and local Singaporeans, supported through the Singapore Kindness Movement, TWC2 and the Ordinary Man initiative. In short, researcher's initial fieldwork was mobilised from a discrete study into an innovative programme of ethnographic research, developing alongside social reform and social media, and developing new knowledge to inform the NGO advocacy work for migrant worker rights. The use of participatory, visual methods with the construction workers proved particularly transformative. It both provided a richer understanding of their everyday lives, and a visual articulation of how they conceptualised their social position within Singapore. It also helped 
to realign what researcher's felt was a misinformed narrative about the workers, as her research was published in the national print media (Lin, 2014). As the next sections explain, the precarious working conditions and social marginalisation of Tamil construction workers in Singapore have been established over several decades, but without receiving adequate empirical study.

\section{Precarious Working Conditions:}

Singapore's heavy reliance on migrant labour is evident in how more than one third of its total workforce consists of non-citizen workers, with construction receiving the largest inflow of foreign labour out of all the sectors. Official employment level statistics for December 2017 report that foreign construction workers account for $73.8 \%$ of employees $(332,800$ out of 450,900) (MOM, 2018). With major building and infrastructure projects such as the construction of a fifth terminal of the airport, and additional highways and rail networks, Singapore's National Population and Talent Division (NPTD) projected an increase of Singapore's construction workload by 50\% by 2050 (NPTD, 2013). Attempts have been made to reduce the number of foreign employees with construction work visas through strategies to prioritise productivity and innovation in the sector and, at the surface level, the number of Work Permit holders in the construction sector can be seen to have declined quite starkly. We would argue that the foreign workload in Singapore's construction industry is unlikely to reduce significantly, with many of the major building and infrastructure projects underway and the rail networks being expanded in phases till the year 2030 (NPTD, 2013).

Irrespective of economic growth and industry transformation strategies, the essential role of low-wage migrant workers in the building of modern Singapore is undeniable. Indeed, Baey 
and Yeoh (2015) argue "a distinct sort of labouring body is produced and demanded" in the construction sector in order to maintain that infrastructure growth. Namely one that is "lowcost, hyper-productive, docile, and disposable" (p.12). Migrant construction work in Singapore is recognised as one of the most precarious forms of labour. Construction fatalities are triple the overall workplace fatality rate. NGOs active in the area argue that unreported work injuries are particularly high, with Healthserve (Chok, 2014) reporting how "excessive work hours and cost-cutting measures" impact workplace safety, with extreme fatigue increasing the risk of accidents happening.

In addition, the weight of debts, state regulations and restrictions and livelihood pressures all produce, what Lewis et al. (2015) refer to as, 'hyper-precarious lives'. For Indian construction workers, the average placement fee paid for their first job was SGD 4,500 (USD 3,375) (Loh 2013). Beyond the employment structures that have imposed precarity, we will later examine empirically and theoretically, through Banki (2013), the added vulnerability produced through the precarity of place, restricting Tamil workers' ability to live freely and securely in Singapore.

This indebtedness has further implications in terms of weakening any bargaining power or means of recourse, with workers tied to a single employer who has the ability to terminate their contracts without penalty. A fact which Baey and Yeoh (2015) attribute to workers sometimes 'choosing' to "endure unsafe and or exploitative working conditions rather than risk the possibility of repatriation" (p. 7). Precarious working conditions in the Singaporean construction sector can too frequently take the form of illegal salary reductions, contract substitution, poor and exploitative working and living conditions. Yea (2017) investigates the strategies of subcontracting companies in the construction and shipyard sectors to discipline migrant worker in the face of worker complaints, summarising that: "For workers with disputes around salary or other conditions of work the aim is to ensure these workers 
continue to labour under exploitative conditions knowing prospects for benefitting from economic justice are likely to be thwarted. For injured workers the aim is to remove workers from the company in a way that invalidates compensation and other claims" (p.186).

In addition to facing physical abuse from foremen and supervisors, Datta (2015: 125) charts the vulnerability of construction workers through examples of employers instigating violence from workers of one nationality against workers of another. For instance, a foreman soliciting Bangladeshi workers to 'beat up' a group of Tamil workers from India when he was not happy with their work. In his study, 68 of the 70 migrant construction workers felt that the Ministry Of Manpower endeavours to support workers during cases of verbal and physical abuse, but felt that agents and employers are "smart enough to manipulate the laws and find a way out" (p. 125).

Yea's (2017) case studies of migrant workers with four different construction subcontractors support the claims by migrant worker NGOs, such as TWC2, that the state-led mediation process for settling a claim is weighted heavily in favour of the employer. When a formal complaint is made over wage issues, abuses or work injuries, a worker is assigned a case worker at the Ministry of Manpower. Having deserted the workplace or having had their permit cancelled, workers are then placed on a new visa category called a Special Pass which does not allow workers to (legally) engage in employment. Again, the prevalence of a range of strategies employed by companies are evidenced, in response to the worker complaints.

In this study, five of the eleven Tamil migrant workers participating in the in-depth interviews were on Special Passes awaiting medical treatment and compensation after workplace accidents, with the other six still working in the construction and allied industries. Our research builds new empirical knowledge of this marginalised group of construction workers, revealing the links between precarity of labour and precarity of place. 


\section{Exclusion of Tamil Workers:}

This research also addresses another neglected area in the literature by not just turning a lens towards the migrant construction labourers, but by focusing specifically on the Tamil workers. While Singapore as a city may have been "over-examined"e (cf. Schiller and Çağlar 2011: 61), we would like to emphasise that there still remains distinct gaps in the study of this city and, particularly, the relationship with its migrants such as low-waged Tamil labour migrants. Through observing the diverse experiences of this group of migrant workers, this article will also contribute to the broadening knowledgebase of South-South labour migration in Asia, which is acknowledged as a "notable feature of international migration" in Asia (UNESCAP 2012: 2). We will also argue that Tamil construction workers in Singapore experience not only precarity at work but also 'precarity of place' (Banki 2013; Sibley 1995).

Despite the historical migration path (Amrith 2010) and their continued presence in Singapore's labour market, Tamil migrants' experiences remain to be included in studies study of contemporary labour migrants in Singapore . Indeed, Sullivan et al. (1992: 70) note there has long been a distinct "hierarchy of foreign workers" in Singapore. Tamil workers have often been presented through the "lens of urban social problems"e (Schiller and Çağlar 2012: 2) in Singapore's newspapers. Kaur et al's (2016) recent analysis of the newspaper coverage of the Little India Riot by The Straits Times, the most popular newspaper in Singapore, argues that there was a framing of the workers as criminals and 'rioters', using stereotypes of mass alcohol consumption and 'street justice' to stand as traits of Indian culture. Low (2002) argues that, while the employment of migrant labour in the construction industry began in the 1980s, the labour policies largely remain unchanged since then. She notes that Singapore 'silently' maintains the ethnic quota to preserve Chinese dominance for 
socio-political reasons (2002: 101). Other scholars (Castles 2000: 107; Hui 1997: 116; Pang and Lim 1982: 549; Tan 2003) have recognised Singapore as having specific policies that encourage the entry of ethnic Chinese immigrants.

The lacuna on the study of Tamil migrants from India resonates throughout wider migration scholarship, as most literature addressing Indian labour migrants has been centred around Malayali migrants from Kerala (Buckley 2012; Gallo 2006; Osella and Osella 2000), while some research on Tamil migrants and refugees from Sri Lanka also exists (Bruland 2011; Fuglerud 2001; George 2011). It must also be highlighted here that recent research on Tamil migrants in the Middle East has included them under the broader term of South Asian labour migrants (Mohammed and Sidaway 2012; Kathiravelu 2012).

As the area in which 11.7 million of the world's 21 million precarious workers are located, it would certainly seem strange for Asia to be overlooked in academic examination, and yet Strauss (2012: 138) and Yea (2017: 180) both point to the lack of sector-specific and ethnographically focused studies of migrant labourers in this part of the world.

\section{Labour market strategy: recruitment and training of construction workers}

A complex and stratified migration regime has developed to supply a construction labour force to Singapore. The training and recruitment of workers in South-East Asian and South Asian countries for Singaporean construction work has become an industry in itself. Accredited overseas testing centres, to train and screen workers at source, have been developed alongside policy changes in Singapore. Migrant workers must pass an exam and then be sponsored by an employer who applies for a work permit for them under the work pass system (MOM, 2017). To be qualified under the basic skilled category (R2), workers need to have been issued with a Skills Evaluation Certificate (e.g. dry walling, welding, and 
painting) by Singapore's Building and Construction Authority (BCA). Basic-skilled workers (also referred to as 'Work Permit' holders, WPHs), are not allowed to bring their families with them, as they must enter the country as individual workers. Indeed, according to Baey and Yeoh (2015: 11), the whole system is designed to keep the work flexible for the employer and precarious for the worker: "WPHs are subjected to a host of stringent policy and bio policing designed to facilitate the cheap extraction of their labour, which ensure that they remain a transient (and disposable) workforce who can be repatriated in periods of economic downturn". Agencies are the new suppliers of construction labour and, in addition to providing the essential qualification for work, they often act as mediators between the migrant workers and sponsor. Yet, Datta (2015) notes how typically recruitment in practice is based on the construction work needed and can deviate far from the course certificate (p.120). A complex process of economic policies and fixities maintain these construction labour market conditions, with companies and workers alike building and adapting strategies to work through the sector albeit from very different positions of power.

In addition to enforced construction sector quotas (for which companies need to employ one full-time local worker for every seven Work Permit Holders ), construction companies are subject to Man-Year Entitlements (MYEs) when employing workers from Non Traditional Source (NTS) countries (i.e. India, Bangladesh, Thailand, China, Sri Lanka, The Philippines) and China. Namely, the Ministry of Manpower imposes maximum periods of employment for Basic-Skilled (R2) and Higher-Skilled (R1) migrant workers from NTS countries of 10 and 22 years respectively. The MOM (2017) explains how this is "designed as an administrative control to ensure... [that] workers remain transient and do not sink roots in Singapore”. At least $10 \%$ of a company's construction Work Permit holders must now be HigherSkilled before any new Basic-Skilled construction workers can be hired, but different routes 
to 'upgrading' workers to higher skilled are available, meaning that less levy is paid and the maximum period of employment can be extended (MOM, 2017).

Debrah and Ofori (1997) also identify a "labour market strategy" in which main contractors sell or allocate a share of their Man-Year Entitlements to subcontractors down the supply chain in order to maintain a "floating pool of skilled and unskilled site labour" to tap into when needed on projects, whilst concurrently absolving the main contractor of contractual obligations to the workforce (p.697). This particularly happens with specialised services, such as piling, scaffolding, electrical engineering (Baey and Yeoh, 2015: 12).

Construction also provides much needed employment, especially for low-skilled or entry level workers, with Tamil construction workers in Singapore representing a classic migrant trajectory from industrializing to industrialised nations (Buckley et al., 2016). While they must enter the country as individual workers, research indicates that the workers (and their families) make their migration decisions with some awareness of the many associated risks and costs. New Economies of Labour (NELM) theory stresses the role of households and families in joint decision-making, beyond the motives of economic, self-interest (see Abreu, 2012). The strategy for income generation in the literature on Tamil migrants is, in line with NELM migration theory, often attributed to improving standards of living and gaining socioeconomic mobility as a family decision. For instance, in the face of precarious work, $59 \%$ of migrant construction workers surveyed by Baey and Yeoh (2015:30) still felt that "daily life for their families back home was either 'easier' or 'much easier"” on account of their migration remittance, with many of the respondents "proud of the fact that they are able to send more money than an educated person holding a job in Bangladesh can" (Datta, 2015: 120). Indeed, as labourer Anjappan reflects on, during the photo diary activity discussed later, despite the restrictions faced by the Tamil workers in Singapore, "those with skills sometimes 
choose to remain gainfully and meaningfully employed, even if it means they face precarity of place" (Banki, 2013: 457).

Ethnographic research provides a means to access and better understand the everyday decision-making and the contingencies and complexities of working construction in Singapore. Bal (2015) highlights a critical and distinctive element of applied, ethnographic research in the context of development work and construction. Namely the need to forge a path away from the construction site in order to enact change for construction workers. His ethnographic research, with male Bangladeshi migrant construction workers in Singapore, charts the informal negotiations (which he calls "tactical accommodation") between construction workers and employers. This ranges from repatriation threats and intimidation from employers (see Datta, 2015), through to individual concessions at work, such as small wage increases or preferred work deployments. However, migrant workers do not enter into these encounters from a position of power but, instead, when faced with workplace injury or a need to improve poor labour conditions. Workers are devoid of collective agency and bargaining power, and subsequently: "tactical accommodation does little or nothing at all to remedy unbearable work and pay regimes, the absence of medical attention after work accidents, the firm's shortage of jobs (and hence, wages), or unpaid wages" (Bal, 2015: 232). Workers also risk being viewed as unproductive, on account of injury or reluctance to work long shifts, or as a troublemaker who needs to be disciplined or removed (Yea, 2017: 180). We maintain that these workers, some of whom participated in our research, experience the extreme conditions of both precarity of labour and precarity of place.

\section{NGOs and applied research}


NGOs have long performed an important role in addressing labour rights issues in construction globally, with non-union labour organisation of particular importance in developing countries and countries with strong state control. In Singapore, it was not until the late 1980s that there was a growth in grassroots activism and the provision of services and skills centres. Piper (2006) documents this relatively short history, explaining that migrant worker rights was largely “"'off-limits” to socially active citizens because of its association with the "Marxist Conspiracy" case in 1987" (p.371). There has been some progress in addressing migrant worker concerns along traditional routes of labour organising, with Piper (2006), for instance, highlighting the improvements made by the Singapore National Trade Union Congress (SNTUC) in the housing and occupational safety of migrant workers in the construction sector. Yet she argues that political activism by migrant workers, or on their behalf by NGOs, plays the primary role in enacting change in the area of migrant employment and working conditions.

Schuller and Lewis (2014) question whether part of the reason that ethnographers have been slow in engaging with NGOs (in terms of research both with and about NGOs), might be because of "the uncomfortable similarity between the work that anthropologists and NGOs do. Both are open to the criticism that they move uninvited into communities where they seek to build relationships with people generally less powerful than themselves" (p.640). In our research, the project was supported in kind, rather than financially, by NGOs, in providing a platform for the research. Yet, within NGO studies there are both arguments about the irresponsibility of research from both camps. There are accusations that academic research in development areas is based on an irresponsible 'extractive' research paradigm unless there is a focus on informing practice (Edwards, 1989), and that NGOs' drive to control and create successful project narratives is equally irresponsible without 'enabling spaces' for research subjects around dissemination and feedback (O'Reilly and Dhanju, 2010). 'Enabling spaces' 
for participants is something that was clearly structured into our research outputs, with the photo diary, and its later public exhibition, despite it originating from an academic space.

Clearly, the reach and remit of academic researchers and NGO practitioners can be differentiated in terms of access to workers, with the previous section establishing how NGO involvement with workers formally begins through instances of worker desertion being converted into case work. Indeed, Feldman (2003) describes how, in the context of Bangladeshi NGOs, the casework can be read as 'depoliticizing poverty', and rendering social problems like inequality and social exclusion into "technical" ones. Yet, the first points of connection between construction workers and the NGOS TWC2 and HOME can also begin through different outreach programmes, which were also the avenues through which researcher met many of the participants for this research. HOME run two help desks (one for migrant construction workers and 'blue collar workers', and another for migrant domestic workers) and shelters for men and women. While TWC2 also run a help desk and Cuff Road Food Programme. The latter, also referred to as a 'soup kitchen', is operated by TWC2 volunteers which in previous years had included researcher and provides a free breakfast and dinner for up to 350 workers daily, who are injured or in disputes with employers. It also provides legal advice on worker rights and their options, and this local knowledgebase informs their advocacy work.

\section{Participatory methods for researching migrant precarity and placemaking}

While she traces an overall growth in the use of visual methods and digital methods in the social sciences, O’Neill (2008) argues that, predominantly, the "visual practices are incorporated as method: the researcher creates or makes use of visual data herself or elicits talk from participants using visual data” (p.3). O’Neill and Harindranath (2006) argue that 
migrants are usually represented by others, such as NGOs, advocacy and support groups, and that it is important that they have the right to represent themselves and are given the space to do so. We attempt to embrace this challenge through the design of participatory visual methods, in order to develop an equal and collaborative relationship between the leadresearcher and the 'co-researchers' (Kramer-Roy, 2015:1222) culminating in worker's 'photo diaries'.

Linda Tuhiwai Smith, a prominent researcher in indigenous studies, stresses the benefits of working "alongside and for communities who have chosen to identify themselves as indigenous" (1999: 5), and her work shares the aims of emancipatory research in explicitly redressing social injustice and increasing self-determination. Yet, her decolonised research approach has the additional aims of decolonising knowledge, that is, of detaching research from imperialism and the legacies of colonial domination.

Acknowledging the theoretical agenda behind ethnography is still a move that is not always made in construction management research. Phelps and Horman (2009), for example, discuss the theoretical model that emerges from the analysis of the data, but argue that their research "begins without a model or preconceived explanation of the phenomena of interest. Ethnography is then used to collect (unbiased) observations over a long period of time" (P.59). The belief that ethnographers necessarily write from a specific subjective position has pervaded anthropology (Edles, 2002: 157), especially after the initial turn to reflexivity in the 1980s (e.g. Clifford and Marcus, 1986), and the continuing challenge of 'atheoretical' ethnography through the development of postcolonial, feminist and postmodernist research. Indeed, this reflexivity and an interventionist aspect has arguably always been present in sociological fieldwork, which Edles (2002: 143) argues first developed in conjunction with 
social reform movements, with a strong focus on marginalised groups within one's own community, from the time of Du Bois' The Philadelphia Negro (1899).

Rather than drawing back from the formal theoretical footing, and the pitfalls of participatory, insider research and its subjective nature, Smith (1999) instead highlights the fundamental problems and biases that such emancipatory research can overcome, by decolonising the methodology and transforming the activity of research. She argues that when indigenous people can become researchers, and not merely the researched or objects of research, there is a key re-positioning: “...questions are framed differently, priorities are ranked differently, problems are defined differently, and people participate on different terms" (Smith, 1999: 193).

O’Neill and Hubbard (2010) utilise biographical mobile methods (which as an embodied research practice involves "walking and talking in a subject-subject relationship" (p.55). This principle of minimising the power relationship through collaborative, participatory methods was at the heart of the photo diary research. Methodologically and ethically this approach of auto-photography can be seen as relating back to the key driver behind decolonised research, that of the "incompatibilities of mainstream research" for engaging with migrant communities (Gobo, 2011: 431). From this perspective, the inherent power imbalance produced through colonial cultural ways of knowing migrants, through surveys and interviews, needs to be overcome, with participatory methods providing a means to decolonize methodology.

It is recognised that photographs, including those taken both during participant observation and by participants themselves as part of participatory 'photo diary' activity, are particularly valuable for urban research, and for helping to convey the "feel of urban places" (Rose 2012: 298). As Pink (2001) explains, gender, ethnicity and other aspects of identity have 
implications for undertaking ethnographic research with images. This brings a need for reflexivity and an awareness, in researchers, of how they represent themselves to participants, as we will discuss in the research positioning section. It is logical therefore that research entailing reflexive, collaborative and/or participatory methods can help "redress the inequalities that inevitably exist between participants and researchers" (p.67). As Rose (2012: 307) observes, photographs can also provide an effective means of exposing social positions and hierarchy. In our research, photography, using disposable cameras that were provided for this research, allowed participants to actively engage with the research process. Participants own images, and the subsequent interviews about their photo diaries, help produce revealing accounts of their everyday experiences. They also offer an alternative to stereotypes and proved to be very useful in realigning these narratives and challenging pre-conceived perspectives about them.

While participatory forms of research help provide a means for making a radical break from traditional social science research approaches and the legacies of colonial domination, Smith (1999) acknowledges the difficulties of demonstrating or contextualising research outcomes, conceding that “...taking apart the story, revealing underlying texts, and giving voice to things that are often known intuitively does not help people to improve their current conditions" (p.3). This is the challenge that our ethnographic research with Tamil migrant construction workers faced.

\section{Fieldwork and methods:}

Both researcher-selected (photo elicitation) and participant-generated photographs (autophotography) were used in the data collection for this research. The methods involved semi- 
structured interviews, complimented by periods of participant observation, and the subsequent use of worker photo diaries, which will be detailed in the following sections.

\section{Interviews:}

Interviews proved to be the best initial method of inquiry for this research, as they enabled the migrant workers to express their perspectives about their daily lives. The recruitment of interviewees focused on Tamil migrant workers from India. The interview sample comprised of eleven workers, aged between 19 and 43, who had gained employment legally in Singapore through a work permit. Three key informants working with two non-governmental organizations that assisted migrant workers were also interviewed. This helped provide an initial triangulation of data and contextual information on, what Low (2002: 96) refers to as, the "unsurprising lack" of official published data on migrant workers and migration in Singapore.

Access to potential participants was first gained through a gatekeeper, who was also one of the key-informants working for an NGO's soup kitchen programme for injured South Asian migrant workers. Five migrant workers, awaiting financial compensation and/or medical treatment after being injured on construction sites, were recruited there. To include different voices in the sample, Tamil migrants from other locations around Singapore were also approached. While City Hall, Beach Road and Geylang are spaces where migrant workers from Burma, Thailand and China respectively congregate, Little India in Singapore was identified as the key location for Tamil workers. As established earlier, it is a popular space for Tamil migrant workers to gather on Sundays. 
Ethnographic observation was primarily focused on Little India during the months of June, July and August 2012, with informal supplementary interviews and additional photographs taken in August 2014. The secondary location for fieldwork was the smaller open construction sites around Singapore (Ang Mo Kio, Clementi and Rochor). During these periods of observation, the researcher recruited six more Tamil migrant workers for interviews. While the men in open work sites were friendly when approached by the researcher, and most granted permission to be photographed and chat, interviews were arranged away from site.

In-depth interviews were carried out with the eleven migrant workers in Tamil language, in Little India, and lasted for an hour on average. They were digitally recorded with each participant's permission, and later translated and transcribed. Although an interview schedule was used, questions were kept open-ended and participants were encouraged to speak freely and openly about their experiences. The interviews provided detailed accounts of their arrival in Singapore, their reasons for choosing to work there, their working experiences, wages, and their social experiences. Interviews were either conducted in coffee shops nearby the workers' dormitory, or at places where some of them were seated waiting for their friends. Notes on interview dynamics and participant observations were also collected in the researcher's fieldwork diary.

Despite the state's claim of their transient status, these migrant workers constitute a semipermanent structural element of the Singapore labour market. The majority of the participants interviewed for this research had worked in Singapore for at least three years, half had laboured for more than five years, with the exception of Anjappan, who had been there for sixteen years. 
Of the eleven male Tamil migrant workers interviewed, six were employed in Singapore; five were on Special Passes awaiting medical treatment and compensation after work site accidents. Table 1 lists the eleven participants and their basic characteristics. For injured workers, the last occupation held before injury is given. All names are pseudonyms.

\section{Table 1: Characteristics of Tamil migrants in the sample}

\section{[Insert Table 1 here]}

The majority of interviewees classified as "direct street approach" were migrant workers whom the researcher met in Little India during Sundays, as for many this was their only day off work. It has been a popular meeting point for Indians since the colonial British period (Siddique and Shotam, 1982), and Sunday was usually a precious time for them to meet and catch up with other workers from the same village or town back in India; to shop for groceries, eat Indian food, and visit the temples. Notably, these gatherings (which is also the scene of the riot with which we opened the article) have been contentious for close to 30 years, see (Hamid, 2015; Baey and Yeoh, 2015; Kornatowksi, 2017; Chang, 2000).

Photo elicitation, which is "the simple idea of inserting a photograph into a research interview" (Harper, 2002: 13), was employed here to begin the discussion, and its use in ethnography is well established both within sociology and anthropology (Banks, 2001; Pink, 2001; Gariglio, 2016; Leonard \& McKnight, 2015). In this case, the particular image was from Singapore tabloid, The New Paper, in 2011, in which a Tamil migrant worker was 
photographed sleeping next to garbage in Little India. It was printed with a headline entitled, "They get drunk, then some fight, defecate in car parks and sleep on the roads, causing traffic hazards. They leave behind their litter, which attracts rats and cockroaches" (The New Paper, 2011). It was chosen as a stereotypical representation of Tamil construction workers from the media, to use at the beginning of the interview as a stimuli to "invoke comments, memory, and discussion" (Banks, 2001: 87), effectively acting as a prompt for participants to explain their understandings and perspectives on the representation of their lives in Little India.

Accessing participant perspectives on the photograph also elicits insights that are not necessarily clear in the image, or from those living outside of the context or distanced from the setting, in this case that of Little India. This was not a linear process of analysis and interpretation. Researcher analysis of the transcripts from interviews preceded the photo diary research. Yet, a decoding stage of photo diary interviews, where participants considered and discussed their photographs with the researcher, also reflected back on these initial interviews. The theoretical framing of the research is detailed in the next section. The analysis of the interviews developed themes around precarity and discrimination on construction sites (precarity of work), and the exclusory practices experienced by workers in their offsite world, in particular in Little India (precarity of place).

\section{Theoretical Positioning:}

The literature review has established the precarious nature of construction work in Singapore. This included informal employment, indebtedness, illegal salary reductions, exploitative and abusive working conditions, and poor treatment of injured workers on Special Passes. 
Neoliberal work regimes have implicated migrant labourers in highly precarious work, whilst simultaneously creating flexibility within the labour market and maximising profit. There has been a growing trend globally towards precarious work (Standing, 2011) and informal construction since the 1970s (Buckley et al., 2016). Situations in which there is a huge potential for investment accompanied by huge resources of cheap labour commonly produces precarious working conditions and exploitation in the sector (Neale and Waters, 2012: 146).

Precarious work is defined by Branch and Hanley (2011) as employment that is "uncertain, unpredictable, and risky from the point of view of the worker" (p.569), and this is felt most acutely by the low-skilled, low-paid workers at the bottom end of the labour market. For Banki (2013), whose theoretical framework guides our analysis, precarity suggests the potential for exploitation (or the looming threat of unemployment), rather than its certain presence. This condition of being vulnerable to exploitation, described in his study of Burmese migrants in Thailand, is linked to having a lack of security (Banki, 2013: 450-1). Following Banki, it is theoretically useful here to structure the experiences of the Tamil labourers, revealed through our research, into precarity of labour and precarity of place, with the roots of both stemming from colonial legacy and neoliberal economic forces.

Precarity of place is described as the absence of the permission to live freely and securely in one's physical place, which is orchestrated through the policies and practices of host governments. Sibley's (1995: 81) concept of the 'geographies of exclusion' is also pertinent here, being concerned with the control exercised by state agencies on migrant populations, which will help us understand the socio-spatial exclusion faced by Tamils as a type of social control. This has everyday implications for the migrant workers, such as "a fear of accessing public transportation, social spaces, and public offices" (Banki, 2013: 453). With an "inability to be mobile - to move from one place to another", and being vulnerable by simply being physically in a public space (Ibid, p.458). Through our analysis, therefore, we will 
endeavour to expand the theoretical concept of precarity of place through empirical examples.

Banki's theory of precarity of place will be explored through our analysis of ethnographic and participatory photographic research. This enables us to scrutinise some of the geographical, social and cultural complexity of the everyday practices and experiences of the Tamil construction workers in the city. This includes the less visible 'exclusionary practices' (Sibley, 1995) experienced by Tamil men in the Singapore area of Little India, which become 'taken for granted' by citizens as an occurrence of everyday life, and yet are revealing of how institutional control is exercised in a society (Sibley 1995: ix). The interview data enables us to first attend to the employment structures that have imposed precarity, and the interweaving of precarity of labour and place. We will then illustrate how applied, participatory methods are used to detail the working of (and even attempt to mitigate) the precarity of place. Crucially, applied ethnographic research in this context enables us to attend to the precarity of place as well as labour precarity, and to provide an empirical examination of this, to help us add substance to the theoretical examination offered by Banki (2013).

\section{Researcher Identity: representing 'insider' (and outsider) knowledge}

The researcher, is a female, third generation born Singaporean of Indian, Tamil heritage, who was in her late twenties while carrying out this research. She had returned to Singapore to carry out the fieldwork, having previously been a volunteer with a migrant worker NGO and their soup kitchen. The researcher reflected in her fieldnotes on how gender and social position made her feel like an outsider at some times, and could intervene to block the 
process of knowledge construction (Chopra, 2004: 37), whilst it helped to bridge the gap and build relationships at others.

As a lone female researcher studying migrant males in an all-male environment, it proved useful having her brother with her on the weekends to make the initial approach and introduction to workers. All interviews were carried out in open spaces; usually in a coffee shop or a modest food establishment within Little India. On the one hand, she felt that her research identity was gendered and she was considered an 'outsider' in this world of migrant male construction workers. Yet being Tamil by descent enabled 'insider' research, defined by Ganga and Scott (2006: 2) as "social interviews conducted between researchers and participants who share a similar cultural, linguistic, ethnic, national and religious heritage". Though certain cultural practices differ from diasporic Tamils and Tamils from South India, the researcher felt able to understand the nuances of the "spoken and unspoken 'language' of the interview" (Ganga and Scott, 2006: 6). Speaking Tamil when approaching prospective participants was felt as vital to attract workers' attention as well as their respect as it served to break down initial barriers between researcher and participants by facilitating her access into the field. While building an identification as 'insider' brought the researcher closer to the participants, it also arguably made participants more aware of their different social positionsthe researcher being a citizen, assumed to be from a middle-class background and a privileged position vis-à-vis their transient status predicated on a temporary work permit. The researcher was very aware of the difference in power relations through her reflective practice, and while she tried to minimize it in different ways, such as by dressing very plainly in an ethnic Indian top, some research encounters very much reinforced their different social positions.

One common and insightful avenue for this was examining the field notes on the way that some coffee shop owners treated the participants in relation to the researcher. Some of the 
shops were not keen to have migrant workers inside without them purchasing goods. While the researcher usually bought coffee or tea and food, on occasions some of the participants had refused these offers leading to altercations. There was also an incident where one of the shopkeepers made unwarranted comments about why the (female) researcher was the one paying for the food. Such encounters saw gender norms and cultural expectations meet and intersect. Indeed, the fact that some of the coffee shop owners gossiped about the workers to her, after they had left the shop, perhaps indicates how the shopkeepers were reading 'insider' identity by way of her shared Singaporean nationality.

\section{Photo Diary:}

Auto-photography, or elicited photography, refers to photographs taken by research participants rather than the researcher, and the representation and discussion of such images becomes a way of emphasising the narratives of marginalised urban groups (Young and Barrett, 2001; Lombard, 2013; Harper, 2002). It provides democratic possibilities, enabling almost any group of participants to share their worlds, irrespective of their written and verbal competencies. This auto-photographic research recognised the Tamil migrant workers as "experts in their environments", particularly as here the objective was to obtain the perspective of migrant workers themselves and work with them rather than "on" them (Kesby et al. 2005: 144).

The photo diary activity with the Tamil workers used auto-photography to reveal their everyday practices and geographies in Singapore. It opened up areas and insights which would have been difficult to access through more conventional techniques such as interviews, 
and allowed us to explore their construction and meaning of place and to turn a lens on, what Young and Barrett (2001) refer to as, "the minor aspects of survival and existence" (p.149).

While the researcher had successfully interviewed eleven male workers, as a lone woman researching in an all-male environment, the task of gaining their participation in the photo diary was more challenging. Similar to Lyon's (2013) experience, using photography was useful for the researcher in overcoming the gender barrier, as discussed in the previous section. In this case, however, she could not enter the construction sites, as workers could put themselves or jobs at risk by entering into research onsite, given the precarious working conditions they face. One participant also pointed out that migrant construction workers have to declare and leave their possessions at the entrance gate of many construction sites before carrying on with their work, and so would be unable to bring in the disposable cameras. Therefore, all the photo diary participants were recruited through the soup kitchen who were either on medical leave, seeking compensation, or about to return home after the end of their contracts. Nevertheless Tutt et al. (2013b) argue that the "offsite processes, socialities and practices" are understudied in construction ethnography, and provide rich insight on the routes into and through the sector. In our research, these visual methods enabled us to see workers' living spaces and arrangements, and the spaces and places they found meaningful, or were restricted to, within Singapore, giving us access to richer and deeper data which otherwise would have been inaccessible.

Pre-purchased and alphabetically labelled disposable cameras were given to participants. Instructions on camera usage were provided with encouragement to capture their everyday experiences and activities, as well as their favourite places, pastimes, and friends in Singapore. They were offered a print of their photographs, as an incentive to put thought and effort into their pictures. Cameras were collected from participants a week later, with a total 
of 108 photographs taken, and films were processed. A set of their respective photos were developed for the participants and given in an album to them.

At one level, participants' photographs can be taken as evidence of their perceptions of themselves and their experience of place. Yet, as Lombard (2013) explains, the challenge of representation and interpretation in auto-photography research is just as relevant as with any form of social research (p.24), and the issue of how to analyse and interpret such images is still relatively unexplored as a way to understand everyday practices and place-making (p.28).

Rather than researcher-driven interpretation, auto-photography such as the photo diary activity, usually involves discussions around the choices made and intentions behind the participant's photograph. For, as Reissman (2008) points out, there is still a need for us to "make arguments in words about images", contextualizing and interpreting them as part of our theoretical inquiry (p.143).

When participants had received the photo albums, the researcher met with them individually to discuss the issues and themes arising from their photographs. These follow-up interviews were critical, in order for the photo diary participant to reflect on why the images were produced. Similar to Moore et al.'s (2008: 55) research experience, the follow-up photo interviews provided a clear insight into the participant photographers' position on the photos, their motivations, thoughts and feelings in relation to the images. Yet the very discussion about their photo diaries also reinforced the workers role in the research process as the 'expert' (Rose 2012: 306), who explained their photographs to the researcher.

However despite the focus on the research participants' perspectives, Bryman (2016) explains that there is no escaping the "double interpretation", in the sense that "the researcher is providing an interpretation of others' interpretations" (p.28). The images and the narrative are 
analysed and interpreted by the researcher in the context of the interview transcripts, and in interaction with existing theorizing and research on the precarity of labour and the precarity of place.

\section{Interview findings:}

\section{Discrimination and precarious work:}

The interviews reveal further discrimination facing Tamil migrants both before they set foot onsite and when they leave work after a hard day's labour. Analysis of the interview data helps elucidate the interweaving of precarity of labour and precarity of place facing Tamil migrant workers. As established in the literature review, South Asian workers were among the lowest paid male migrant workers, receiving \$18 daily. Vikram, 34 years old, who has been working in Singapore's construction industry for eight years, stated that he was receiving a daily fixed rate of $\$ 18$ SGD for an average of 9-10 hours of work. He informed us that he has been employed directly by a construction company that is rated to be the second biggest construction company in Singapore:

When I asked for a raise of at least $\$ 1$, my manager, a Singaporean Chinese, came up to me and said 1 Singapore dollar is equivalent to 40 Indian rupees, how can I raise it? They have pegged our salary to India's economy. $\$ 1$ is 40 rupees, calculate how much $\$ 18$ will be. The same work that I do when done by a worker from China, he gets at least $\$ 50$ or more a day.

Labourer Velu, 32, echoed Vikram's experience: 
Normally, if you look at Chinese workers, for one day they must be paid a minimum of $\$ 40$. An Indian worker, it is $\$ 18 \ldots$ If you ask why, they say the money value is different in their country, that is why this difference.

There is no minimum wage legislation in Singapore and the authority regulating foreign manpower, the Ministry of Manpower, has left it to market forces. While the rate differs by nationality for all other migrant workers from various countries such as China, Thailand and Myanmar, workers from Bangladesh and India are categorised together and paid similar lower wages. This reveals hidden forms of racism and also perhaps cultural protectionism (Chia, 2008: 110). Pay differentiation based on nationality is discriminatory but well established, and Key Informant 1 referred to this as a 'prejudice rooted in stereotypes':

It's there, an attitude, because it's not really contested, it lingers on and then it becomes an excuse to be judging people not on what their skills are or their dedication, but because you are from this place and you look this way and that's why you deserve to get $\$ 10$ less per day. You know, it's ridiculous but it's there.

Another differentiation was found in the language of the skills test taken by migrant workers; Key Informant 1 confirmed that workers from China and Thailand could sit their tests in their own languages, while workers from Bangladesh and India have usually had to take it in the English language in the past. Recently some of the Skills Evaluation Certificate SEC(K) trade tests have been made available in Tamil language. Despite this positive change, courses and tests for Construction supervisors are conducted in English, Mandarin and Thai languages only (BCA, 2018). This is an example of differential treatment, with privileges bestowed upon certain nationalities while linguistic restrictions are placed on others. The significance of Tamil language to their experience in Singapore, is drawn out further in the photo diary discussion. 


\section{Little India}

Most participants identified Little India as their favourite place to visit in Singapore outside of work, with many rarely venturing into other parts of the city. Velu informed us that he had even heard about Singapore's Little India before he came to Singapore. His classmate, who had previously worked in Singapore, had told him that it was a place where Indians gathered. Upon arriving, Velu felt that Little India was a place that anyone could easily fit in:

Here [Little India] you can see everyone, from a normal person to a rich person, shop here. If you go Orchard Road, normally we don't have a budget for that. Everything is catered for the rich person. But we cannot say the same about Little India. It's OK, everything is for the rich as well as the ordinary person who does normal work. They too can purchase things. If you look at Orchard Road, only the rich people can shop there and eat there. Secondly, all the Indian vegetables can only be found here in Little India, you can't find it in other places in Singapore.

The above interview quote shows that Velu's relationship to Singapore is shaped by his feelings of inclusion in Little India, and exclusion from other places such as Orchard Road, the popular Central Area shopping belt with many malls selling luxury designer goods.

Yet, the Tamil migrants' experiences of living and working in Singapore is also defined by their in/ability to move freely through these spaces. Siva, 38, a construction worker who has been working in Singapore for over a decade, succinctly expressed the importance that Tamil migrant workers attach to Little India, and how changes incorporated within this space have affected these workers:

Nowadays when a worker first arrives in Singapore from Changi airport, he comes to Little India first. It's really well known. In the past we could go near the [apartment] 
blocks in Race Course but now [we are] not allowed at all. How many thousand men can squeeze near the MRT [train] station? Now you cannot stand near any blocks or roads. The same for rubbish bins, sometimes it is full and overflows and they fine us. This precarity of place was first explored through the use of photo elicitation. The interviewees were shown the newspaper image to elicit their response, which was printed with the headline: "They get drunk, then some fight, defecate in car parks and sleep on the roads, causing traffic hazards. They leave behind their litter, which attracts rats and cockroaches $^{\text {ee }}$ (The New Paper, 2011).

While all the participants acknowledged that workers drank in Little India in their free time, they were quick to add that it was a small number of them who got drunk, and on Sundays only, or who could be related to this narrative. In Siva's words:

This is stereotyping of all men sleeping on pavements as drunks. Sometimes they miss the last train and do not have any other way of going home and men are not allowed to bring their friends into their dormitory. Hence sometimes some men sleep there without any choice. Sometimes it's an emergency and they do not have any other way... Cannot say all are drunks- that is wrong. Singapore government sells the drinks. It is their source of income too. If they do not make them available 24 hours, a lot of our men will be better.

Kumaran shared a similar sentiment about missing the last trains, and added:

The reason why there is rubbish is because all the bins get filled up by around 8 p.m., because there are a lot of people here. All the shops are selling and remain open here, because of us they always have good business here.

Participants from the soup kitchen explained that some injured Tamil workers who have run out of money do sleep on the streets as they await compensation claims. While they are 
denied any form of monetary assistance from the state, they are also no longer allowed to work, representing another form of exclusion. As established in the literature review, legal migrant workers who are injured are not allowed to work and do not have access to any form of financial assistance from the state (HOME and TWC2 2010: 2; Rahman 2010: 212), thus it is not surprising that some resort to sleeping on the streets.

Young (1990: 59) identifies the production of the common stereotype that Indians are alcoholics as a form of cultural imperialism. To return to Sibley’s (1995: 5) geographies of exclusion, here the Tamil migrants are further represented as being 'disorderly' and needing to be policed and supervised. By photographing the worker sleeping next to garbage, the migrant is portrayed as an object of pollution and thus made abject (Ibid, p.62). Yet the interviews indicate that there is little to no interaction with these 'othered' migrant workers; they do not read the state's English newspapers which 'feature' them. Hence, Tamil migrants have been positioned and defined by a dominant discourse from the outside and the stereotyped views are not contested.

\section{Articulating their (precarious) place in Singapore:}

When asked in interview how Tamil migrants view their position within Singapore, all participants stated that they saw themselves as being there only temporarily. Anjappan mentions that, despite working there for 16 years, and though he would like to continue to work and contribute, employers and the state still viewed him as transient. Muthu expressed that this realisation is at its starkest when one gets injured. The statement below exemplifies the sentiment shared by most participants that, regardless of their health conditions and fitness to work, all workers knew they were highly dispensable: 
Singapore and the employers throw us away like how we throw away our banana leaf after we are done eating.

Despite being aware of their transient and dispensable nature, they viewed their labouring as a collective contribution that Singapore has built on, with Anjappan explaining that, "with our Indians' hard work, Singapore has developed well'e. These views are echoed by Velu:

It is the foreign workers who have come here and developed this country, leaving their own country, come here and toil for this country's development. But yet this country does not bother about us.

Velu, speaking with such conviction, illustrates that low-waged Tamil migrants are acutely aware of their important contribution to Singapore. They understand the value that their active labouring has brought to Singapore. Such narratives are indicative of the resilience of low-waged migrant workers. The constant physical change of Singapore is similar to New York, which de Certeau (1984) describes as remaking and reinventing itself "from hour to hour, in the act of throwing away its previous accomplishments and challenging the future" (p. 91). Thus low-waged Tamil migrant labour have and will continue to play a "crucial and varied role" in making Singapore competitive within Asia as well as internationally (Schiller and Çağlar, 2011: 12). Again, labour and place (and their precarious status) became inseparable, not least by leaving their physical imprint on the built environment. In the photo diary activity that follows, Anjappan chose to take a photograph of Esplanade Theatres (see Image 3), one of Singapore's new, high-status developments which he took great pride from having worked on. Yet the interviewees felt that the essential role played by Tamil migrant workers is contradicted by their spatial marginalisation at various levels.

\section{(Restricted) Living in the City:}


Similar to Dubai's residential camps for workers (see Mohammed and Sidaway, 2012), migrant workers are housed in dormitories around the periphery of Singapore, "hidden away in industrial areas of the city" (Kendall 2012: 46). While the workers in the Gulf States are housed out in the desert, migrant workers in Singapore are housed next to the cemetery. Interviewee, Siva, is one of the 12,000 migrant workers living next to the cemetery in dormitories in Lim Chu Kang, where public transport is sporadic. Hence these migrant workers are effectively isolated from the city.

While Tamil workers are not meant to be seen, and are uncomfortably dispersed around the edges of Singapore, all the migrant workers interviewees visit Little India to remit, rest, and rejuvenate before the beginning of yet another physically demanding week. This however has been a bone of contestation with the local residents who live in residential apartment blocks around Little India. These apartment blocks are public housing flats meant only for citizens and permanent residents (PRs) as a privilege (Chua, 2000).

The residents have articulated their anxieties through familiar stereotypes, complaining that the congregating migrant workers are noisy and dirty; they are unwanted in their neighbourhood. Indeed, they have been writing to the press and their Member of Parliament since these foreign workers began arriving in Singapore some twenty years ago (Hamid, 2015: 16; Long, 1995). As the interviews indicate, while some workers might transgress, the majority of workers just want to meet their friends. As they are not welcomed in the shopping malls nearby, these workers have little choice but to gather around empty public spaces to socialise.

Similar to Low's (2003) research in New York City and San Antonio, where residents installed entry gates and guards to exclude Mexican migrant workers, residents in Little India have, since the 1990s, had their residential blocks installed with metal barriers and fences. A 
residents' committee and the neighbourhood police also placed signs in Tamil and Bengali cautioning workers not to "loiter" (Hamid, 2015: 16). Hence, such spatial boundaries also represent the 'moral boundaries' imposed on the workers by the residents (Sibley 1995: 39). Interviewees described how some resident patrol teams even resorted to spraying water on the floors below apartment blocks to prevent these workers from gathering. The residents of Little India have gained "power through spatiality" (Massey, 1997: 104), by employing such spatial tactics to impose social control in public spaces, to keep migrant workers apart.

While these physical boundaries provide comfort and security to the residents, such examples also illustrate that the established residents of Little India represent themselves as "insiders"e who are threatened by the presence of the marginal "other" (Sibley 1995: 14). They have expressed their anxieties through stereotypes of migrant workers, a group Standing (2011: 90) has cautioned to be in danger of being "demonised and made scapegoat of problems not of their making" (p.90).

Through interviews, participants also voiced the differential way in which they felt policing was carried out. Velu describes how migrant workers were singled out and monetary fines were imposed on them while Singaporean citizens were let off for the same 'mistakes' such as littering of cigarette butts:

In the same place, if a Singaporean had done something wrong, they will see it but they will not go and approach them or confront them, they will just keep quiet. But if a foreign worker makes a slight noise, they immediately run to us and ask. They see that difference.

Siva shared a similar sentiment on the presence of police in Little India:

Sometimes when we are walking on the street, just minding our own business, the Singapore police will stop us and ask 'why are you walking here', and 'what are you 
doing here?' There might be some problems around that area, even though we [Tamil migrant workers] have nothing to do with it. But when a worker from China walks past, the police do not stop and check them. Because they have been given a lot of rights. Even if they do something wrong, they are let off... I can't meet my friends daily. I can only see them on Sundays in Little India. This place has a lot more business on Sundays and this benefits the Singapore government right? There are a lot of people, it is very crowded in Little India and this helps businesses as people spend their money.

The above narratives of Velu and Siva illustrate how the surveillance, or social control, in Little India discriminated by ethnicity and nationality. For the Tamil labourers, this differential use of power by the auxiliary policemen renders their position as low-waged construction workers even lower and more precarious. The gradual deployment of signs, followed by the barriers and police patrols, follows the residents repeated requests of the state for stronger defences to counter the perceived dangers of the gathering migrant workers. This exemplifies de Certeau's (1984) example of how a public space can be made "private" to regulate "social interaction" and the "use of space" by Tamil workers (p. 81). These interview extracts illustrate that, while labouring in the 'global' city, the only place Tamil migrant workers have found comfort and inclusivity, and where they feel closest to home, is Little India; yet, even here, they still face a precarity of place.

\section{Photo Diary:}

\section{Living in leftover spaces and in-between places}


The newspaper image with headline was shown to the workers during interviews, as a form of photo elicitation, to encourage their reflections on and reactions to their media portrayal. However, it was through the participatory research of the photo diary that we were able to access a visual counter-narrative, authored by the Tamil migrants themselves.

The photographs discussed in this section have been selected to directly reflect on the precarity of labour and place, in order to help develop our understanding of this in relation to Tamil construction workers in Singapore. We argue that Ramu's photographs offer an insight into the everyday lives of low-waged migrant Tamil workers, while Anjappan's images offer counter-narratives to the stereotyped common (mis)representations of their lives and labour. Ramu's photographs can be seen as capturing the Tamil labourers' ways of 'making do', or bricolage (de Certeau, 1984). That is, the creative opportunities and tactical play that occur in gaps between patterns of everyday life. Yet these 'tactics', as de Certeau terms them, are the actions of the non-powerful, forced to adapt and appropriate the (pre-existing) environment. For instance, with his image of a makeshift stall in a car park in Little India, Ramu captures a place where many migrant men go to purchase cheap clothes on weekends. Siva explains how migrant workers navigate their way around Little India by creating little pockets of space for themselves. Some have done this by claiming other "leftover spaces", similar to migrant workers in Abu Dhabi (Elsheshtawy, 2011), which Ramu's photographs document very well. de Certeau (1984) defines a 'tactic' as 'a calculated action determined by the absence of a proper locus ...thus it must play on and with a terrain imposed on it and organized by the law of a foreign power' (p. 37). Without a 'proper locus', the tactician's ownership or occupation of a space can only be temporary.

Ramu shared the photograph below of Tamil migrant workers having their lunch on a back lane pavement in Little India as illustration. 


\section{Image 1 here}

Sitting on drain covers on a narrow street, the migrant workers are able to manipulate the space available to them in order to share a meal together with friends. Both Ramu and Vikram go to particular streets to meet kinsmen from their hometowns. Ramu, from the Ramanathapuram district of Tamil Nadu, said in interview: "There are different areas within Little India, where workers from different areas in Tamil Nadu meet. My friends and I meet near the Chander Road area".

The makeshift use of this pavement away from residential blocks illustrates this tactical play as the Tamil migrant men seek alternative spaces and appropriate them. Given the contestation of space in Singapore's Little India, this photo was a good way to see the migrant men's agency in appropriating other un-wanted spaces.

During the follow up interview, Ramu explained that he wanted to show the daily life of workers such as himself: the places they sit, meet, eat meals together, and also sometimes shop. He captures the places they gather and their use of space within Little India; this is the very definition of bricolage. Ramu explained that he stood at a distance to picture the scene. In doing so, the images are useful in offering key glimpses of the hidden (or otherwise invisible) everyday life of Tamil construction labourers, and the (lack of) space for these workers in the highly contested terrain of Little India. In terms of geographies of exclusion, these images document the creativity, as well as the desperation, in appropriating space within the constraints of social order, before this order was temporarily ruptured with the Little India riots. 
This photograph below, taken by Ramu (Image 2), enables us to have a view inside the dormitory of his fellow migrant construction workers. It also sheds light on the lived realities and conditions they face; a view not easily accessible and visible to researchers and others. As much of the detailed ethnographic observation carried out with migrant construction workers have tended to be on construction sites (Löwstedt, 2015; Thiel, 2013; and Tutt et. al, 2013a), these photos provide a window into an important yet hidden and largely underresearched aspect of construction workers lives. By studying lives outside construction sites, we are able to gain an important insight into the living conditions of the workers. Living conditions do affect upon the psychosocial wellbeing of migrant construction workers (Hamid, 2014; 2015). Amnesty International has highlighted the plight of migrant construction workers in Qatar, where some have been on the brink of suicide (Amnesty International, 2013a; 2013b). Construction companies subcontract to labour supply companies and agencies, who are now the real suppliers of labour, and this research demonstrates how it becomes too easy for companies to turn a blind eye to how workers are recruited, their living conditions or how (much) they are paid, rather than ensuring their supply chains are free of labour abuses.

Image 2 here: Interior of a dormitory, housing 60 workers in a single room. Image taken by Ramu, photo diary project.

Ramu's photograph, taken indoor, in a more private space, illustrates the interior of a dormitory housing workers in a single room. While the actual space and length of the room is not immediately obvious, the beds piled one on top of the other, with rows of bunk beds next to each other and laundry hung on the bed, is indicative of the space - and the lack of space afforded to them. He explained how most dormitories are usually overcrowded with poor sanitation: a clear indication of the low social position occupied by migrant workers in Singapore. One can imagine the cheek by jowl distance between each migrant worker in their 
rooms. de Certeau (1984) reminds us that "the space of a tactic is the space of the other"; it is "the art of the weak" (p.37). With the 'absence of a proper locus', the worker's ingenuity and creativity are stifled; the photograph brings home the precarity of place and the difficulties of 'making do'. Tactics can "only use, manipulate, and divert spaces", and here there is quite literally no room for manoeuvre.

Ramu's photos have illustrated the everyday life and lived reality of the low-waged migrant worker, in Little India and Singapore generally. He documents the spaces they live, shop for cheap clothes over the weekend as well as the spaces they appropriate for themselves to meet, catch up and share a meal. Such everyday lived realities do affect the experience of the worker. These photographs are valuable as they shed light on spaces and lives of these migrant workers, which is not normally accessible to researchers and others. As noted earlier, work sites are highly securitised and are usually closed to researchers. Being a female, it would have posed an even greater challenge and obstacle for the researcher to carry out observations in construction sites and dormitories. Yet having this photograph taken by Ramu himself has provided us with an authentic insider view.

\section{Capturing the shared and built heritage}

Ramu's photographs concentrate on the Tamil migrants' opportunistic, short term uses of space, as a creative 'art of the weak'. In contrast, Anjappan uses his photographs to question this temporariness and argue that Tamil construction workers have a long-standing history in the 'establishment of a place' and have physically marked their names on the city. Beyond the precarious nature of their work and place in the city, he builds historic connections between the Tamil labourers that have built, and those that will continue to build, Singapore. 
Anjappan started out as a bricklayer initially, and then after several years underwent forklift training in Singapore. This was followed by electrical training years later, with his last job being an electrical fitter in Singapore. Anjappan took a photograph of the distinctive Esplanade Theatres, framed in the foreground by crowds of visitors, families and tourists (Image 3 below). This was followed by an image of groups of schoolchildren waiting outside the Marina Bay City Gallery for their visit.

\section{Image 3 here}

Anjappan explained in the interviews that he took this image as he had worked in the construction of the Esplanade Theatres fixing the electrical wirings. He also excitedly told the researcher that he saw the then American President Obama there during the 2009 APEC Meeting's evening cultural event, which was held in the Esplanade in Singapore. Anjappan's company was hired to provide back-up electricity and he was maintaining the generator. He takes great pride in having contributed his labour to the building, and in the international reach of the built environment he has helped create.

Reflecting on the changing landscape of Singapore, and his role here, he remarked that: "I keep telling myself another 1 or 2 years to fulfil my duties, but the years keep running ... [I have] built a house and now my children have started studying, so I need to spend on them". Anjappan is the sole breadwinner in his family: He has a daughter and a son and takes care of his elderly mother and the medical expenses for her illness. His 'temporary' status as a migrant labourer has now extended well over a decade in Singapore. Aligned with the theories of NELM discussed earlier, his economic migration journey became shaped by the needs and joint decision making of the family. When queried about his photograph of the school children awaiting their visit to the Esplanade galleries, he explained that it signifies 
how education is important and that the site facilitates learning for the next generations. He explained that he wants to make sure his children get well educated, unlike himself who did not have that opportunity.

Anjappan also focused his lens on other landmarks and monuments with meaning to him, such as photographing the Window of Hope sculpture in Collyer Quay, Singapore. When queried about these photos, he explained that he felt connected to the sculpture and what was written there as he himself arrived in Singapore with hopes for a better future, just as his ancestors, and those of the researcher's, had done. Significantly, Anjappan has been working construction in Singapore for 16 years, the longest duration of all the participants. Hence, he was more conscious than most of the historical Tamil connection, with labour from India having been a significant feature of colonial migration since the founding of modern Singapore in 1819 (Rai, 2006: 176). For Anjappan, choosing the Window of Hope sculpture for his photo diary marked a powerful reminder of Singapore's migrant past and futures; representing the hopes that migrants carry along with them and the strength of the historical ties that Singapore share with India.

Through Anjappan's images, we are reminded of the commonalities between local citizens and migrant workers -Singaporeans and Tamil migrants - as well as the shared linguistic heritage, and important historic links between Singapore and India. The image below is of a monument built in memory of the Indian National Army in Singapore, with the financial contribution from the Indian community of Singapore.

\section{Image 4 here}

When queried about the reasons behind this photo, Anjappan stated that it again featured the longstanding historical connections with India, but that here it was the use of the Tamil 
language that helped exemplify it. For Anjappan this marks the importance given to Tamil language in Singapore: "Even within India when I was working in Andhra [Pradesh], you cannot hear or see as much Tamil language there. Here there is importance given to Tamil language... I have the same feeling as I have in Tamil Nadu".

The interviews flagged the workers' inability to take their construction skills test in their own language, unlike workers from China and Thailand. This is despite the prevalence of the Tamil language in the construction sites and city, and it being recognised as an official language of Singapore. Banki (2013: 451) notes how precarity of one kind can often aggravate other precarities. The exclusion of Tamil language, which represents a feature of precarity at work, can be seen as weakening the worker's ties to Singapore captured in this photograph. These linguistic choices have been examined in other contexts, with Tutt et al (2013b) considering the implications of the different languages options for the Construction Skills Certification Scheme (CSCS Card) test in the UK, which is mandatory to work on construction sites. However, in the context of everyday exclusionary practices of host governments examined here, the decision can be viewed as another way of 'writing out' the common Tamil migrant heritage of Singapore construction.

Yet, Anjappan's photographs plot the positive imprint of Tamil migrant workers in the bricks and cultural heritage of Singapore: they are written into the very fabric of the modern day city. To return to de Certeau's (1984) theories of 'making do', Anjappan's photographs illustrate some of the ways that Tamil construction workers can be seen as countering this 'temporariness', by working strategically towards the "establishment of a place" that resists "the erosion of time"(p.38). These stand in stark contrast to the clever, temporary claims on (pockets of) space captured in the photographs of Ramu. 
The process of the photo diary research purposely involved 'taking apart the story' (Smith, 1999), following the goals of decolonised research, and giving a 'face' and 'voice' to the workers which, as established, had been absent from the dominant discourse in the local media. While the photo diary led to a larger project involving Singaporean students, migrant construction workers, and subsequent public display of images at the Parallel Paths exhibition, it also provided a means to address (even redress) the injustices and inequalities by opening the dialogue in such ways alongside NGO support.

\section{Conclusions:}

Construction sector deregulation is a global feature that has led to increased migration flows into the sector creating a supply of flexible, insecure and internationalized construction labour (Buckley et al., 2016). This highly mobile and disposable migrant construction workforce has been growing strongly in countries where laws prohibit citizenship and residency rights for migrants, particularly across Southeast Asia and the Persian Gulf. Yet, there has been little contemporary ethnographic research undertaken that engages directly with manual workers and/or the topic of working conditions in Construction Management research areas, despite the acknowledgement that applied ethnographic interventions in the construction industry are very achievable (Pink et al., 2012).

Ofori and Debrah (1997) highlight how the weaknesses of the construction labour subcontracting in Singapore, and its intensifications at times of labour shortage, is not a recent, peripheral or short-term strategy but, rather, the "traditional basis of the industry". Yet, they note that calls for fundamental changes in the way construction workers are managed, and attempts to discourage the use of, or to 'reform', the labour subcontracting 
system, have continually been defied (pp. 404-5). NGO and academic research (HOME and TWC2, 2010; Yea, 2017) have also consistently highlighted how unsafe worker behaviour is linked with their precarious employment conditions. The literature review sections have established the precarious nature of construction work in Singapore: indebtedness from high recruitment fees; low salaries and illegal salary reductions; a fear of raising grievances against employers who could discipline or remove them from site; and poor treatment of injured workers on Special Passes working conditions. These conditions conspire to push workers to accept longer hours and exploitative and abusive working conditions. Other research has highlighted how employers avoid reporting workplace injuries, with Yea (2015) documenting how false police reports filed by construction subcontractors, against migrants threatening to file a Ministry of Labour complaint, is a common tactic used by employers. Our research follows some of the construction labourers injured at work, on medical leave and/or seeking compensation, who face further obstacles in accessing labour justice.

This article has built out of the researcher's reaction to the Riot in Little India in December 2013, which followed a fatal traffic accident involving a Tamil construction worker. We have established how, despite labouring for three decades and being connected to the existing Tamil diasporic community there, Tamil migrant construction workers have been left out of state rhetoric and face economic marginalisation and social exclusion. In terms of geographies of exclusion, the photo diary images document the creativity, as well as the desperation, in appropriating space within the constraints of the social order, before this order was temporarily ruptured with the Little India riots.

The analysis of the interview data develops themes around precarity and discrimination on construction sites (precarity of work), and the exclusory practices experienced by workers in their offsite world, in particular describing surveillance and social control in Little India (precarity of place). While the Tamil construction workers took great pride in their 
construction of Singapore, they explain how this essential role is controverted by their spatial marginalisation at various levels.

Through our analysis, therefore, we have endeavoured to expand the theoretical concept of precarity of place (described as the absence of the permission to live freely and securely in one's physical place, which is orchestrated through the policies and practices of host governments). The visual, participatory methods enabled the Tamil construction workers to present their lives through their own lens, providing a visual articulation of how they conceptualised their social position within Singapore. This enables us as researchers to scrutinise some of the geographical, social and cultural complexity of their everyday experiences in the city, as we empirically build a picture of both the exclusionary practices they faced, and their everyday management (and mitigation) of them. We have added substance to the theoretical examination offered by Banki (2013), by scrutinising these spatial practices. We use de Certeau (1984) to break down the concept of precarity of place into the times that workers act tactically, to "use, manipulate and divert spaces" (in the absence of one's own place), and when they work strategically to question temporariness, through decades of labouring in Singapore (to establish one's own place).

We focused in this article on two diaries. We argue that Ramu's photographs offer an insight into the everyday life and living conditions of Tamil construction workers, and the (lack of) space for these workers in the highly contested terrain of Little India in Singapore. While Anjappan's images offer counter-narratives to the stereotyped common (mis)representations of their lives and labour, representing the common Tamil migrant heritage of Singapore construction and the strength of the historical ties that Singapore share with India.

Elsewhere, Schiller and Çağlar (2011: 61) document how migrant place making can lead to the regeneration of places, creating new communities, and businesses etc., and even transforming "institutions of power and the patterning of social life in specific places" (p.79). Yet this paper, and Ramu's photo diary in particular, have demonstrated how in Singapore this place making for Tamil migrants is policed, stifled and repressed, leading to informal 
expression in the nooks and crannies of the city. Ramu and his fellow workers, many having lived in the city for well over 5 years, must vigilantly make use of the left over spaces and the "cracks that particular conjunctions open in the surveillance of the proprietary powers" (de Certeau, 1984: 37).

We have also begun the journey of moving from empirically understanding their plight to making changes. Following the goals of decolonised research, our research gives a 'face' and 'voice' to the Tamil construction workers, which has been absent from the dominant discourse in the local media. We demonstrate how the use of innovative methods provide a means to address the injustices and inequalities by opening dialogue, alongside NGO support, through subsequent public exhibition of the photographs and presence in the national print media.

Within a context where reforms to migrant labour laws come not from applied research at construction sites and worker dormitories, but from engaging with construction workers once they leave site through injury or absconding, this visual ethnographic research developed new knowledge to help inform the NGO advocacy work for migrant worker rights. All the photo diary participants were recruited through the soup kitchen who were either on medical leave, seeking compensation, or about to return home after the end of their contracts. Taking accountability for management of workers, and their health, safety and welfare onsite at an operational and ethical level, begins with construction companies taking more responsibility for how their workers first enter and leave their projects. Construction companies' responsibility to migrant workers must go beyond the corporate veil, hiding layers of subcontracting recruitment, to ensure the supply chain is free of labour abuses by treating any workers onsite as their employees. 
We have been highly reflexive in detailing the researcher's positioning and identity in the field and the theoretically driven nature of the ethnography, employing innovative, participatory methods with a social interventionist research agenda to enact change (Smith, 1999). The ethnography was formally theoretical, in continually bringing theoretical questions into dialogue with the ethnography. Yet, such research can be highly ethical on the micro level, facilitating improvements in the lives of participants. By developing a blog post based on the research for publication on migrant worker rights NGO website, Transient Workers Count Too (TWC2) (Hamid, 2013), we could feed directly into the media debate. Such research can provide a firm basis for policy and advocacy work to design interventions for increasing the developmental outcomes of migration for construction workers. In this case, it led to a new project of auto-photographic research with migrant construction workers and local Singaporeans supported by the Singapore Kindness Movement, TWC2 and the Ordinary Man initiative (Lin, 2014).

While NGOs are linked into national and global systems, the power of their intervention in this context is in offering local-level "participation, empowerment, and alternatives to existing (state-led) methods and structures", indeed for Rigg (2007) it is this which places the actions of NGOs in the field of politics (p. 150)

The use of participatory, visual methods with the construction workers proved particularly transformative. It both provided a richer understanding of their everyday lives, and a visual articulation of how they conceptualised their social position within Singapore. While it shed light on an under-researched group on one hand, on the other it also helped to realign a misinformed narrative about the workers. 
Measuring the effects and impact of these counter narratives, to common media stereotypes of Tamil construction labourers (Kaur et al., 2016; Hamid, 2015), are beyond the reach of this project or the remit of this qualitative research. There are always new means to develop, and new opportunities to challenge, the participatory element of ethnographic research.

By involving the migrant workers and employing applied and innovative ethnographic methods, this article has highlighted the two types of precarities faced by Tamil migrant construction workers. Additionally, it has also shown how precarity follows the workers offsite, heeding Tutt et al's (2013b: 11) call to trace the "continuities between onsite and offsite processes, socialities and industry practices, which influence migrant workers' experiences of the sector". The simple fact that, in order to make a difference to worker welfare and working conditions onsite, researchers and NGOs need to engage with workers offsite is perhaps most revealing of the precarious situation facing Tamil construction labourers in Singapore.

\section{References}

Abreu, A, 2012. The New Economics of Labor Migration: Beware of Neoclassicals Bearing Gifts. Forum for Social Economics 41(1), 46-67.

Amnesty International., 2013b. The Dark Side of Migration. [online]. Available from https://www.amnesty.org.uk/files/the_dark_side_of_migration__spotlight_on_qatars_construction_sector_ahead_of_the_world_cup.pdf [Accessed 10 November 2015].

Amrith, S.S., 2010. Mobile city and the Coromandel Coast: Tamil journeys to Singapore, 1920-1960. Mobilities, 5(2), 237-255. 
Baey, G. and Yeoh, B.S., 2015. Migration and precarious work: Negotiating debt, employment, and livelihood strategies amongst Bangladeshi migrant men working in Singapore's construction industry. Migrating Out of Poverty Working Paper, 26

Bal, C.S., 2015. Production Politics and Migrant Labour Advocacy in Singapore. Journal of Contemporary Asia, 45(2), 219-242.

Banki, S., 2013. Precarity of place: a complement to the growing precariat literature. Global Discourse, 3(3-4), 450-463.

BCA, 2018. Building and Construction Authority, Singapore. BCA Website, https://www.bca.gov.sg/academy/Faq.aspx\#FA0016; [Accessed 26 September 2018].

Branch, E.H. and Hanley, C., 2011. Regional convergence in low-wage work and earnings. 1970-2000. Sociological Perspectives, 54(4), 569-592.

Bruland, S., 2011. Nationalism as meaningful life projects: identity construction among politically active Tamil families in Norway. Ethnic and Racial Studies, 1-19.

Bryman, A., 2016. Social Research Methods. Oxford: Oxford University Press.

Buckley, M., 2012. From Kerala to Dubai and back again: construction migrants and the global economic crisis. Geoforum, 43(2), 250-259.

Buckley, M., Zendel, A., Biggar, J., Frederiksen, L., Wells, J., 2016. Migrant Work \& Employment in the Construction Sector. International Labour Office: Geneva, ILO.

Castles, S., 2000. Ethnicity and Globalization. London: Sage.

Chang, T.C., 2000. Singapore's Little India: A Tourist Attraction as a Contested Landscape. Urban Studies, 37 (2), 343-366.

Chia, S.Y., 2008. Demographic change and international labour mobility in Southeast Asiaissues, policies and implications for cooperation, In: G. Hugo and S. Young, eds. Labour Mobility in the Asia-Pacific Region: Dynamics, Issues and a New APEC Agenda. Singapore: Institute of Southeast Asian Studies, 93-128.

Chok, S., 2014. Risky Business: Death and Injury on Singapore's Construction Sites. Singapore; Healthserve: http://www.healthserve.org.sg/what-we-do/

Chua, B. H., 2000. Public Housing Residents as Clients of the State. Housing Studies, 15(1), 45-60.

Clifford, J. and Marcus, G.E. eds., 1986. Writing culture: The poetics and politics of ethnography. Univ of California Press.

Datta, S., 2015. Bangladeshi Muslim construction workers in Singapore: A study in the process of migration and employment. Islam Realitas: Journal of Islamic and Social Studies, $1(2), 117-127$.

de Certeau, M., 1984. The Practice of Everyday Life. Berkeley: California University Press. 
Debrah, Y.A. and Ofori, G., 1997. Flexibility, labour subcontracting and HRM in the construction industry in Singapore: can the system be refined?. International Journal of Human Resource Management, 8(5), 690-709.

Du Bois, W.E.B. and Eaton, I., 1899. The Philadelphia Negro: a social study (No. 14). Published for the University.

Edles, L.D., 2002. Cultural sociology in practice. Malden, MA: Blackwell.

Edwards, M., 1989. The Irrelevance of Development Studies. Third World Quarterly 11,11635 .

Elsheshtawy, Y., 2011. Informal Encounters: Mapping Abu Dhabi's Urban Public Spaces. Built Environment 31 (1), 92-113.

Feldman, S., 2003. Paradoxes of Institutionalisation: The Depoliticisation of Bangladeshi NGOs. Development in Practice 13(1), 5-26.

Fuglerud, Ø., 2001. Time and space in the Sri Lanka-Tamil diaspora. Nations and Nationalism, 7(2), 195-213.

Gallo, E., 2006. Italy is not a good place for men: narratives of places, marriage and masculinity among Malayali migrants. Global Networks, 6(4), 357-372.

Ganga, D., Scott, S., 2006. Cultural "insiders" and the issue of positionality in qualitative migration research: moving "across" and moving "along" researcher-participant divides. Forum Qualitative Social Research, 7(3), Art. 7, [On-line Journal] http://www.qualitativeresearch.net/index.php/fqs/article/view/134/289. [Accessed 26 Sep 2018].

Gariglio, L., 2016. Photo-elicitation in prison ethnography: Breaking the ice in the field and unpacking prison officers' use of force. Crime Media Culture, 12(3), 367-379.

George, G., 2011. The Canadian Tamil diaspora and the politics of multiculturalism, Identities, 18(5), 459-480.

Gobo, G., 2011. Glocalizing methodology? The encounter between local methodologies, International Journal of Social Research Methodology, 14(6), 417-437.

Hamid, W., 2013. Seen but Unheard [online]. Transient Workers Count Too (TWC2). Available from: http://twc2.org.sg/2013/12/13/seen-but-unheard/ [Accessed 26 September 2018].

Hamid, W., 2014. Migrant Labour in Asia: Singapore's Recent Riot [online]. Asia Pacific Memo 260, Available from: http://www.asiapacificmemo.ca/migrant-labour-singapore. [Accessed 26 September 2018].

Hamid, W., 2015. Feelings of Home amongst Tamil Migrant Workers in Singapore's Little India. Pacific Affairs, 88(1), 5-25.

Harper, D., 2002. Talking about pictures: a case for photo-elicitation. Visual Studies, 17(1), 13-26. 
HOME and TWC2., 2010. Justice Delayed, Justice Denied: The Experiences of Migrant Workers in Singapore - 2010 Report, Singapore. Available from:

http://twc2.org.sg/2010/12/15/justice-delayed-justice-denied/ [Accessed 26 Sep 2018].

Hui, W.T., 1997. Regionalization, economic restructuring and labour migration in Singapore. International Migration, 35 (1), 109-128.

Kathiravelu, L., 2012. Social networks in Dubai: informal solidarities in an uncaring state. Journal of Intercultural Studies, 33(1), 103-119.

Kaur, S., Tan, N., and Dutta, M.J., 2016. Media, migration and politics: The coverage of the Little India Riot in The Straits Times in Singapore. Journal of Creative Communications, 11 (1), 27-43.

Kendall, D., 2012. Always let the road decide: South Asian labourers along the highways of Dubai, UAE: a photographic essay. South Asian Diaspora, 4(1), 45-55.

Kesby, M., Kindon, S., Pain, R., 2005. Participatory approaches and diagramming techniques. In R. Flowerdew and D. Martin, eds. Methods in Human Geography, A Guide for Students Doing a Research Project. $2^{\text {nd }}$ ed. Essex: Pearson Education Limited, 144-165.

Kornatowksi, G., 2017. Caught up in policy gaps: distressed communities of South-Asian migrant workers in Little India, Singapore. Community Development Journal, 52(1), 92-106.

Kramer-Roy, D., 2015. Using participatory and creative methods to facilitate emancipatory research with people facing multiple disadvantage: a role for health and care professionals. Disability \& Society, 30 (8), 1207-1224.

Lam, E., 2013. Little India riot: Avoid inflammatory rhetoric. The Straits Times, $10^{\text {th }}$ December.

Leonard, M. \& McKnight, M., 2015. Look and tell: using photo-elicitation methods with teenagers. Children's Geographies, 13(6), 629-642.

Lewis, H., Dwyer, P., Hodkinson, S., \& Waite, L., 2015. Hyper-precarious lives: Migrants, work and forced labour in the Global North. Progress in Human Geography, 39(5), 580-600.

Lin, M., 2014. Seeing Singapore through the eyes of migrant workers. The Straits Times, $7^{\text {th }}$ March 2014. Available from: https://www.straitstimes.com/singapore/seeing-singaporethrough-the-eyes-of-migrant-workers

Loh, Y.C., 2013. Survey Uncovers Exorbitant Agent Fees Suffered by Bangladeshi Workers. Available from: http://twc2.org.sg/2013/08/29/survey-uncovers-exorbitant-agent-feessuffered-by-bangladeshi-workers/

Lombard, M., 2013. Using auto-photography to understand place: Reflections from research in urban informal settlements in Mexico. Area, 45 (1), 23-32.

Long, S. 1995., Looking after tourists, foreign workers. The Straits Times, 27 January. 
Low, L., 2002. The political economy of migrant worker policy in Singapore. In: D.Yaw, ed. Migrant Workers in Pacific Asia. London: Frank Cass and Co, 95-118.

Low, S., 2003. The edge and the center: Gated communities and the discourse of urban fear. In: S. Low and D. Lawrence, eds. The anthropology of space and place: Locating culture. Malden: Blackwell, 387-407

Löwstedt, M., 2015. Taking off my glasses in order to see': exploring practice on a building site using self-reflexive ethnography. Construction Management and Economics, 33(5-6), 404-414.

Lyon, D., 2013. The building and the body in space and time. In: S., Pink, D. Tutt, and A. Dainty, eds. Ethnographic Research in the Construction Industry. Abingdon: Routledge, 2340 .

Massey, D., 1997. Space/power, identity/difference: Tensions in the City. In: A. Merrifield and E. Swyngedouw, eds. The urbanization of injustice. New York: New York University Press.

MOM. 2018. Ministry of Manpower Singapore. Labour Market Statistical Information, Summary Table: Employment. Released on: 13 June. Available from: http://stats.mom.gov.sg/Pages/Employment-Summary-Table.aspx

MOM., 2017. Ministry of Manpower Singapore. Construction sector: Work Permit requirements. Available from: http://www.mom.gov.sg/passes-and-permits/work-permitfor-foreign-worker/sector-specific-rules/construction-sector-requirements

Moore, G., Croxford, B., Adams, M., Refaee, M., Cox, T., \& Sharples, S., 2008. The photo-survey research method: capturing life in the city. Visual Studies, 23(1), 50-62.

Neale, R. and Waters, J., 2012. Safety and health in construction in developing countries: The humanitarian paradox. In: G. Ofori., ed. Contemporary Issues in Construction in Developing Countries. Abingdon, Oxon: SPON Press, 144-189.

NPTD (National Population and Talent Division), 2013. A sustainable population for a dynamic Singapore: Population white paper. Singapore.

O’Neill, M. and Hubbard, P., 2010. Walking, Sensing, Belonging: Ethno-mimesis as performative praxis. Visual Studies 25 (1), 46-58.

O'Neill, M., 2008. Transnational Refugees: The Transformative Role of Art? Forum Qualitative Sozialforschung / Forum: Qualitative Social Research, 9(2), Art. 59: http://www.qualitative-research.net/index.php/fqs/article/view/403

O'Neill, M. \& Harindranath, R., 2006. Theorising narratives of exile and belonging: The importance of biography and ethno-mimesis in "understanding" asylum. Qualitative Sociology Review, 11(1), 39-53. 
O’Reilly, K. and Dhanju, R., 2010. Your Report is Completely Wrong!' (aapkii report ek dum galat hai!): Locating Spaces Inside NGOs for Feedback and Dissemination. Human Organization 69(3), 285-294.

Osella, C., Osella, F., 2000. Migration, money and masculinity in Kerala, The Journal of the Royal Anthropological Institute, 6(1), 115-131.

Pang, E. F., Lim, L., 1982., Foreign labor and economic development in Singapore, International Migration Review, 16(3), 548-576.

Phelps, A.F. and Horman, M.J., 2009. Ethnographic theory-building research in construction. Journal of Construction Engineering and Management, 136(1), 58-65.

Pink, S., 2001. Doing Visual ethnography. Images, Media and Representation in Research. London: Sage.

Pink, S, Tutt, D., Dainty, A., 2012. Introducing Ethnographic Research in the Construction Industry. In: S. Pink, D. Tutt, A. Dainty, eds. Ethnographic Research in the Construction Industry. London: Routledge, 1-22.

Piper, N., 2006. Migrant Worker Activism in Singapore and Malaysia: Freedom of Association and the Role of the State. Asian and Pacific Migration Journal, 15 (3), 359-380.

Rahman, N.A., 2010. Managing labour flows: foreign talent, foreign workers and domestic help. In: T. Chong, ed. Management of Success: Singapore Revisited. Singapore: Institute of Southeast Asian Studies, 199-216.

Rai, R., 2006. Indians in Singapore. In: B.V. Lal, P., Reeves, R. Rai., eds. The Encyclopedia of the Indian Diaspora. Singapore: Editions Didier Millet, 176-188.

Rigg. J., 2007. An everyday geography of the Global South. London: Taylor and Francis.

Rose, G., 2012. Visual Methodologies: An Introduction to Researching with Visual Materials London: Sage Publications.

Schiller, G.N., Çağlar, A., 2011. Locality and globality: building a comparative analytical framework in migration and urban studies. In: G. N. Schiller, and A. Çağlar., eds. Locating Migration: Rescaling Cities and Migrants. Ithaca: Cornell University Press, 60-81.

Schuller, M. and Lewis, D., 2014. Anthropology of NGOs. In: Jackson, J., ed. Oxford Bibliographies in Anthropology. Oxford University Press: New York, USA.

Siddique, S. and Shotam, N.P., 1982. Singapore's Little India: Past, Present \& Future. Singapore: National Heritage Board.

Smith, L.T., 1999. Decolonizing methodologies: Research and Indigenous peoples. New York: Palgrave.

Standing, G., 2011. The Precariat: The New Dangerous Class. London: Bloomsbury Academic. 
Strauss, K., 2012. Coerced, forced and unfree labour: Geographies of exploitation in contemporary labour markets. Geography Compass, 6 (3), 137-148.

Sullivan, G., Gunasekaran, S., Siengthai, S., 1992. Labour migration and policy formation in a newly industrialized country: a case study of illegal Thai workers in Singapore. ASEAN Economic Bulletin, 9(1), 66-84.

Tan, E.K.B., 2003. Re-engaging chineseness: political, economic and cultural imperatives of nation-building in Singapore. The China Quarterly, 175, 751-774.

The New Paper, 2011. Little India Residents Woes. The New Paper, 20 June.

Thiel, D., 2013. Ethnography and flux. Identity and epistemology in construction fieldwork. In: S., Pink, D. Tutt, and A. Dainty, eds. Ethnographic Research in the Construction Industry. Abingdon: Routledge, 73-90.

Tutt, D., Pink, S., Dainty, A. and Gibb, A., 2013a. The communication practices of migrant workers in the UK construction industry. In: S., Pink, D. Tutt, and A. Dainty, eds. Ethnographic Research in the Construction Industry. Abingdon: Routledge, 40-57.

Tutt, D., Pink, S., Dainty, A. R., \& Gibb, A., 2013b. Building networks to work: an ethnographic study of informal routes into the UK construction industry and pathways for migrant up-skilling. Construction Management and Economics, 31(10), 1025-1037.

TWC2., 2018. Foreign Workforce Number 2017. Available from: http://twc2.org.sg/2018/05/22/foreign-workforce-numbers-2017/

Yea, S., 2017. The art of not being caught: Temporal strategies for disciplining unfree labour in Singapore's contract migration. Geoforum, 78, 179-188.

Young, I.M., 1990. Justice and the Politics of Difference. Princeton: Princeton University Press.

Young, L. and Barrett, H., 2001. Adapting visual methods: action research with Kampala street children. Area 33 (2), 141-152. 